\title{
Chemical Structure of Mangrove Species Rhizophora stylosa as Natural Dyes
}

\author{
Paryanto*, Sunu Herwi Pranolo, Ari Diana Susanti, Kristina Ratna Dewi, Meydiana Rossari \\ Chemical Engineering, Faculty of Engineering, Sebelas Maret University \\ Jl. Ir. Sutami 36A Jebres, Surakarta Jawa Tengah 57126 Indonesia \\ Email: paryanto.uns@gmail.com
}

\begin{abstract}
Textile dyes are divided into two types, natural dyes and synthetic dyes. Natural dyes commonly made from extraction. Extraction is a process in which one or more components are separated selectively from a liquid or solid mixture, the feed, by means of a liquid immiscible solvent. Extraction can be classified into two group, liquid extraction and solid-liquid extraction. Solvents that are usually used in the extraction of natural dyes are aquades and ethanol. The purpose of this research was to determine the chemical structure, especially tannin in natural dyes from mangrove species Rhizophora stylosa through several samples testing natural dyes. Rhizophora stylosa that have been extracted and evaporated will conducted several tests to obtain chemical structures in natural dyes and yield of tannin in natural dyes. Tests carried out include testing FT-IR, and HPLC. Based on FT-IR analysis, the extraction of Rhizophora stylosa containing tannin indicated by the presence of hydroxyl $(\mathrm{O}-\mathrm{H})$ in the area of $3385.36 \mathrm{~cm}^{-1}$, aromatic $(C-H)$ in the area of $1365.53 \mathrm{~cm}^{-1}$, carbonyl $(C=O)$ in the area $1646.36 \mathrm{~cm}^{-1}$, esters (C-O) in the area $1217.30 \mathrm{~cm}^{-1}$. While tannin content obtained from the analysis of HPLC were $6.087 \mathrm{ppm}$.
\end{abstract}

Keywords : chemical structure.mangrove, tannin

\section{INTRODUCTION}

Batik in Indonesia has a comparative advantage in the economic field (Setiawati et al., 2015). The high demand for batik both domestically and abroad, the more dyes are used. Textile dyes are divided into two types, natural dyes and synthetic dyes. Synthetic dyes can be derived from coal or crude oil which are the product of aromatic hidrocarbon such as benzene, naphthalene, and anthracene. The use of synthetic dyes has been proven to be cheaper but have a negative impact because they are carcinogenic, due to the heavy metal content of synthetic dyes (Paryanto, et al., 2012). Compared to natural dyes, synthetic dyes have the advantage in the resulting color, color variations, price, availability, to stability (Lee, et al., 2005). However, judging from its constituent components, the use of dyes that contain chemicals to the use of wax that is insoluble in water causes problems in the surrounding environment (Manurung, 2012). Natural dyes are biodegradable and less toxic and allergenic than synthetic dyes, they are considered to be environmentally friendly (Punrattanasin et al., 2013). Natural dyes can be obtained from various plant, one of which is mangrove tannin content in mangroves can be used as a natural coloring agent (Purnaningtyas, 2014).

Natural dyes are known for their use in coloring of food, leather, wood, as well as natural fibers like wool, silk, cotton and flax since ancient times (Punrattanasin et al., 2013). Subsequent developments in the use of natural dyes were displaced by synthetic dyes found, because of their superior color resistance properties, they are not easy to fade, are easily produced, the color direction is more varied, and the price is cheaper than natural dyes (Kasmudjiastuti, 2017).

Natural dyes comprise of colorants that are obtained from animal or vegetable matter without any chemical processing (Umbreen et al., 2008). 
Natural dyes have been used for many purposes especially in textile sector such as the colouring of natural fibres, cosmetic, to produce ink, watercolour and artist's paints (Baha et al., 2011). Most dyes are obtained from plants because plants have a variety of color pigments unlike in animals. Pigments contained in plants depend on the chemical structure contained in these plants. Tannin is a natural coloring pigment in the form of a brown coloring agent (Rahim et al., 2007). The purpose of this research was to determine the chemical structure, especially tannin in natural dyes from mangrove species Rhizophora stylosa through several samples testing natural dyes.

\section{METHODOLOGY}

Extraction of natural dyes was carried out at the Chemical Engineering Laboratory, Faculty of Engineering, Sebelas Maret University. Extraction is carried out for \pm 1 hour and evaporation is carried out \pm 45 minutes 4 times. The following materials and tools will be used for the extraction of natural dyes Rhizopora stylosa mangroves and water. The tools used in this study were extractor-evaporator, HPLC (High pressure liquid chromatography), and FT-IR spectrophotometer.

The preparation stage is by chopping and drying the mangrove Rhizophora stylosa in an oven at $100^{\circ} \mathrm{C}$ for 3 hours. The extraction stage is carried out by inserting dried mangrove stylosa into the extractor-evaporator tube and adding water with a ratio between mangrove: water, that is 1:10 (Paryanto et al., 2016). Arranging the extractorevaporator then igniting the stove and the stirring motor. The extraction process lasts for 1 hour at a temperature of $96^{\circ} \mathrm{C}$. The evaporation stage is carried out by opening the evaporator faucet for 45-60 minutes. Equation by Crisholithus (2008).

\section{RESULTS AND DISCUSSION}

In the process of taking pigments of natural dyes required a comparison between ingredients and solvents is 1:10. Dried mangroves used as much as 250 grams and as much as 2.5 liters of water solvent. The extraction process lasts for 1 hour at a temperature of $96^{\circ} \mathrm{C}$ followed by an evaporation process for \pm 45 minutes. From the extraction and evaporation process a volume of concentrate of $1.8 \mathrm{~L}$. was obtained.

The test results with FT-IR obtained FT-IR spectrum data of mangrove fruit species Rhizophora stylosa shown in Figure 3. In the FT-IR spectrum of mangrove fruit Rhizophora stylosa species showed the presence of hydroxyl $(\mathrm{O}-\mathrm{H})$ in the area of $3385.36 \mathrm{~cm}^{-1}$, aromatic $(\mathrm{C}-\mathrm{H})$ in the area of $1365.53 \mathrm{~cm}^{-1}$, carbonyl $(C=O)$ in the area of $1646.36 \mathrm{~cm}^{-1}$, esters (C-O) in the area of 1217.30 $\mathrm{cm}^{-1}$.

Table 1. Results of FT-IR Mangrove Rhizophora stylosa

\begin{tabular}{cc}
\hline Functional Groups & Peak $\left(\mathrm{cm}^{-1}\right)$ \\
\hline O-H (hydroxyl) & 3385.36 \\
C-H (aromatic) & 1365.53 \\
C=O (carbonyl) & 1646.36 \\
C-O (esters) & 1217.30 \\
\hline
\end{tabular}

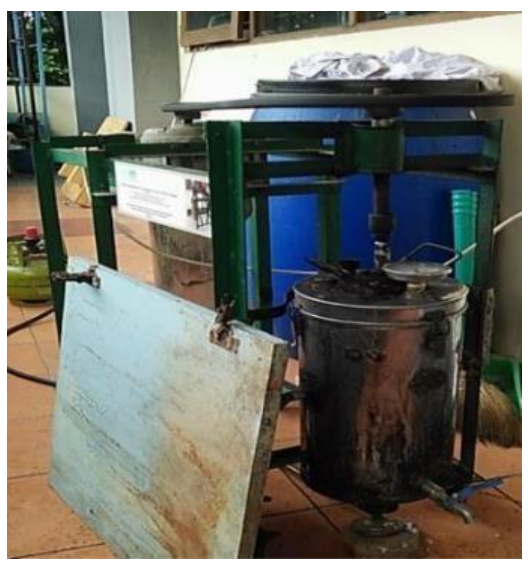

Figure 1. Extraction-Evaporator 
According to Danarto et al (2011), the main tannin element is the hydroxyl group and there are other groups such as carboxyl.According Kasmudjiastuti (2014) in his research on the characterization of high bark as a vegetable tanner. High wood bark containing tannins was tested by FT-IR spectrophotometry obtained that the results of the high FTIR spectrum showed the presence of hydroxyl groups $(\mathrm{VO}-\mathrm{H} ; \mathrm{VN}-\mathrm{H})$ in the area $(3467,418-3057,025) \mathrm{cm}^{-1}$, aromatic group $(\mathrm{VC}-\mathrm{H})$ in the area of $2875,733 \mathrm{~cm}^{-1}, \mathrm{VC}=\mathrm{O}$ (ester group in tanned material) in the area $(1747,442-1612,422)$ $\mathrm{cm}^{-1}, \mathrm{v}-\mathrm{OH}$; R-COO- in the area of $1444,626 \mathrm{~cm}^{-1}$ and $\mathrm{V}\left(\mathrm{SO}_{4}\right)$ 2-; $\mathrm{R}-\mathrm{SO}_{3} ; \mathrm{R}-\mathrm{SO}_{3} \mathrm{H}$ in the area $(1112,823-1062,729) \mathrm{cm}^{-1}$.

In a study conducted by Fatma et al. (2018) analyzed mangroves of rhizophora mucronate with FTIR spectrophotometer. Generate FTIR spectrum data of mangrove fruit species of Rhizophora mucronate on the absorption of $3370.58 \mathrm{~cm}^{-1}$. The next absorption occurs at $1650.50 \mathrm{~cm}^{-1}$. The last absorption is also the weakest at $1271.11 \mathrm{~cm}^{-1}$. When compared to studies conducted by Fatma et

al. (2018) mangroves have hydroxyl $(\mathrm{OH})$ groups, carbonyl groups $(C=O)$, and ester groups ( $\mathrm{CO}$ ). This was confirmed by Marais et al. (2006) revealed that flavonone is a building unit of proanthocyanidin compounds which are condensed tannins. Parubak (2013) who found that the flavonoid compounds from the flavonone group had a $\mathrm{OH} \mathrm{OH}$ functional group, $\mathrm{CH}$ aliphatic, $\mathrm{C}=\mathrm{O}, \mathrm{C}=\mathrm{C}$ Aromatic, $\mathrm{C}-\mathrm{O}$ and $\mathrm{C}-\mathrm{H}$ aromatic. So it can be said that the research we have done is right.

Test results with High-Performance Liquid Chromatography (HPLC) with the following operating conditions: 1 . Flowrate: $1 \mathrm{~mL} / \mathrm{min} ; 2$. The mobile phase: $\mathrm{MeOH}$ : $\mathrm{H} 20$ (50:50); 3. $\lambda$ (long gel): $271 \mathrm{~nm} ; 4$. Column: C18, $250 \mathrm{~mm}$. From the results of three replicas of the tannin standard (Figure 4) using a chromatogram, the following data are obtained (Table2). From the results of two replicas of the mangrove Rhizophora stylosa natural dyes (Figure 5), the following data were obtained Table 2.

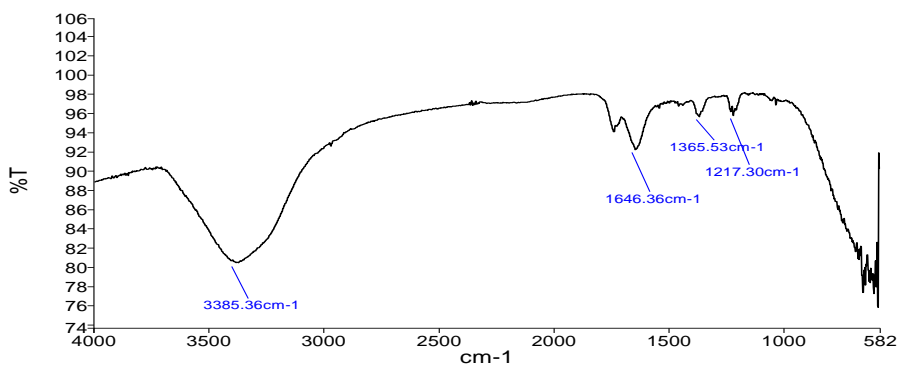

Figure 2. Rhizophora stylosa FT-IR Spectrum

Table 2. Standard Tanin Chromatogram Analysis

\begin{tabular}{cccr}
\hline Sample & Retention time (min) & Area (mAu) & High \\
\hline Standard tanin 4 ppm & 2,886 & 215585571 & 35292817 \\
Standard tanin 4 ppm (2) & 2.949 & 233383331 & 35409043 \\
Standard tanin 4 ppm (3) & 2.959 & 218262186 & 33942994 \\
\hline Average & & 222410363 \\
\hline
\end{tabular}

Table 3. Table of Analysis of Natural Dyes Chromatograms from Mangrove Rhizophora stylosa

\begin{tabular}{cccc}
\hline Sample & Retention time $(\mathrm{min})$ & Area $(\mathrm{mAu})$ & High \\
\hline Stylosa natural dyes & 2,964 & 37630883 & 5177837 \\
Stylosa natural dyes (2) & 2.969 & 30061043 & 4568279 \\
Average & 33845963 & \\
\hline
\end{tabular}




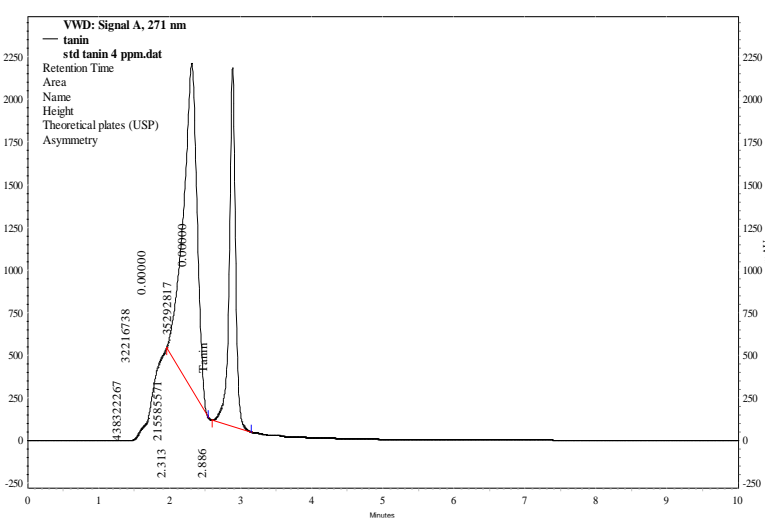

(a) Replica Graph 1

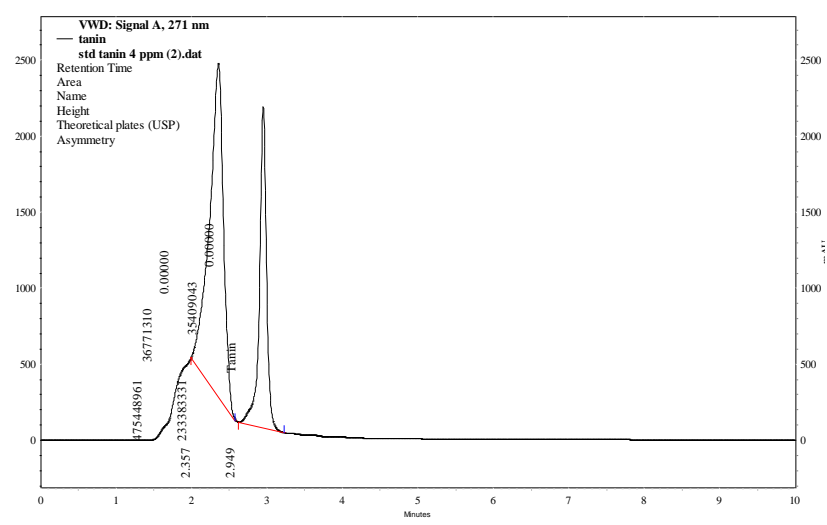

(b) Replica Graph 2

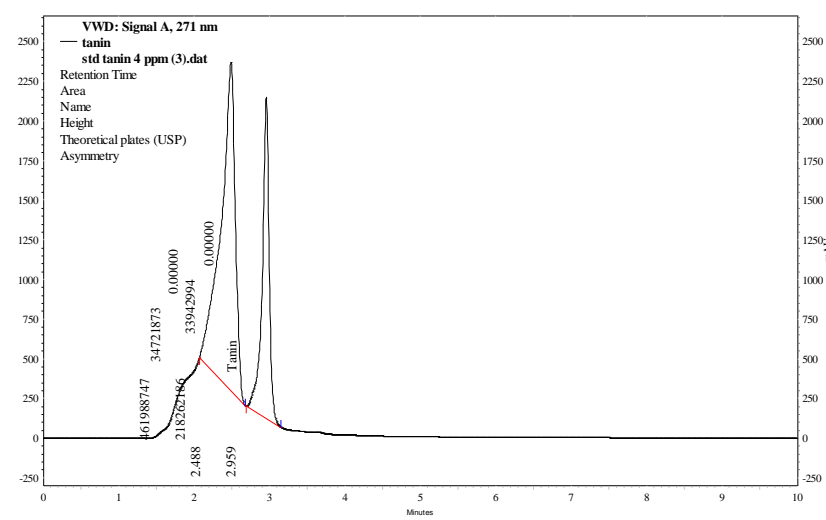

(c) Replica Graph 3

Figure 3. Tanin Standard Replica Chart

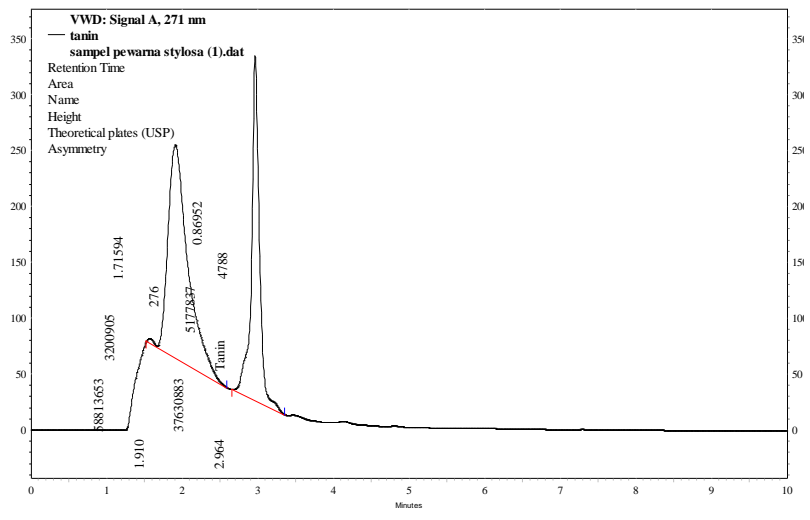

(a) Replica Graph 1

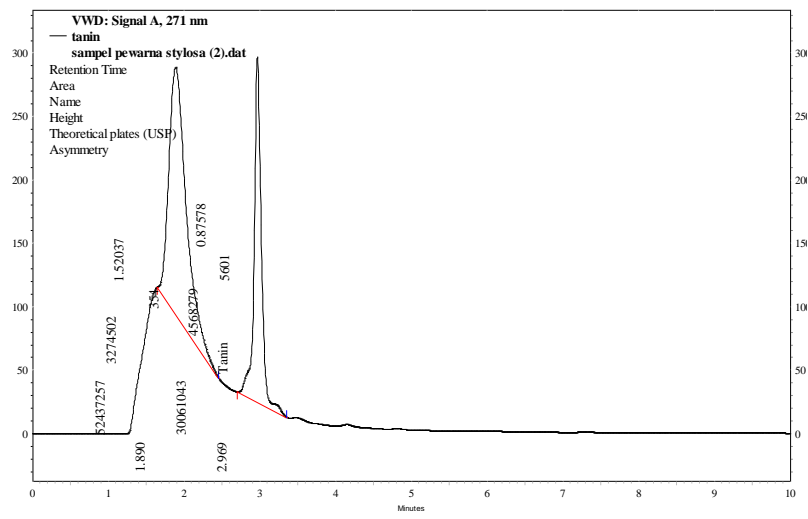

(b) Replica Graph 2

Figure 4. Graphic Replication of Natural Dyes from Mangrove Rhizopora stylosa

From the results of two replicas of the mangrove Rhizophora stylosa natural dyes (Figure 4), the following data were obtained Table 3. With the data that has been obtained from the replica results, it can be calculated the concentration of tannins in natural dyes from mangrove species Rhizophora stylosa. The initial sample is diluted 10 times then taken $1 \mathrm{~mL}$ and diluted again 10 times. 
So the dilution factor is 100 times. Average wide standard area of $4 \mathrm{ppm}=222410363 \mathrm{mAU}$ Average wide stylose sample area $=33845963 \mathrm{mAU}$

Standard concentration $=4 \mathrm{ppm}=>0.004 \mathrm{mg} / \mathrm{mL}$

$$
\begin{aligned}
\text { Tannin content } & =\frac{33845963 \mathrm{mAU}}{222410363 \mathrm{mAU}} \times 0,004 \frac{\mathrm{mg}}{\mathrm{mL}} \times 10 \\
& =0,00608712 \mathrm{mg} / \mathrm{mL} \\
& =6,08712 \mathrm{ppm} \text { Tanin }
\end{aligned}
$$

So, tannin content in the Rhizophora stylosa sample were 609 ppm.

In the research of Hardoko et al. (2015) mangrove fruit species Rhizopora Mucronata has a tannin content of $819 \mathrm{ppm}$. The tannin content in the mangrove fruit species Rhizophora stylosa is smaller than the mangrove type Rhizopora Mucronata species, this is because the size of the mangrove fruit species Rhizophora stylosa is smaller than the size of the mangrove fruit species Rhizopora Mucronata. This was confirmed by the study of Sudarmadji (2004) mangrove Rhizopora Mucronata type which has a fruit shaped like a guava, size 2-2.3 cm, yellowish green color, hypocotyl cylindrical diameter of 2-2.5 cm, length can reach $90 \mathrm{~cm}$, while mangrove Rhizophora stylosa species have fruit similar to the shape of water guava, brown color, size $1.5-2 \mathrm{~cm}$, hypocotyl 2-2.5 cm in diameter, smooth surface, length can reach $30 \mathrm{~cm}$.

The strength of our research is that it is the first research on the chemical structure of tannins in mangrove fruit species of Rhizophora stylosa, so that they can be used as a reference and this research can also optimize the use of natural dyes from Rhizophora stylosa mangrove fruits for batik cloth dyes in Indonesia so as to reduce the use of synthetic dyes that are harmful to humans and the environment.

\section{CONCLUSION}

Based on FT-IR analysis, the extraction of Rhizophora stylosa mangroves containing tannin was indicated by the presence of hydroxyl $(\mathrm{O}-\mathrm{H})$ in the area of $3385.36 \mathrm{~cm}^{-1}$, aromatic $(\mathrm{C}-\mathrm{H})$ in the area of $1365.53 \mathrm{~cm}^{-1}$, carbonyl $(C=O)$ in the area of $1646.36 \mathrm{~cm}^{-1}$, esters (C-O) in the area of 1217.30 $\mathrm{cm}^{-1}$. While tannin content obtained from the analysis of HPLC were 608.712 ppm.

\section{ACKNOWLEDGMENTS}

The authors gratefully acknowledge the financial support of the Director General of Higher Education Research via PTUPT (2019 -2020) and UMKM Batik Soul Craft Group Kuwiran, Banyudono, Boyolali for giving the opportunity for the research.

\section{REFERENCES}

Influence of sunlight on absorption spectra of Rhizophora Apiculata dye solutions. 2011 IEEE Colloquium on Humanities, Science and Engineering, 675-676.

Crisholithus, S. 2008. Laporan Praktek Kerja Profesi Farmasi Industri di PT. Kimia Farma (Persero) Tbk. Plant Bandung. Sumatra Utara : Universitas Sumatera Utara.

Danarto, Y.C., Prihananto, A.S. \& Pamungkas, A.Z. 2011. Pemanfaatan Tanin dari Kulit Kayu Bakau sebagai Pengganti Gugus Fenol pada Resin Fenol Formaldehid. Prosiding Seminar Nasional Teknik Kimia "Kejuangan", 1-5p.

Fatma, D. L., Pringgenies, D., \& Ridlo, A. 2018. Pemanfaatan Mangrove Rhizophora mucronata Sebagai pewarna Alami Kain Katun. Journal of Marine Research, 7(2):79-88.

Hardoko, E.S., Puspitasari, Y.E. \& Amalia, R., 2015. Study of ripe Rhizophora mucronata fruit flour as functional food for antidiabetic. International Food Research Journal, 22(3):953-959

Kasmudjiastuti, E. 2014. Karakterisasi kulit kayu tingi (Ceriops tagal) sebagai bahan penyamak nabati. Majalah Kulit, Karet, dan Plastik, 30(2): 71.

Lee, J., Wroolstad, R.E. \& Derst, R.W. 2005. Determination of Total Monomeric Anthocyanin Pigmen Content or Fruit Juices, Beverages, Natural Colorants, and Wines by the $\mathrm{pH}$ Differential Method: Collaborative Study. Journal of AOAC International, 88(5):1269-1275.

Manurung, M., 2012. Aplikasi Kulit Buah Manggis (Garcinia Mangostana L.) Sebagai Pewarna Alami pada Kain Katun secara PreMordanting, Journal of Chemistry, 6(2):183-190.

Marais, J.P.J., Deavours, B., Dixon, R.A. \& Ferreira, D. 2006. The Stereochemistry of Flavonoids. The 
Science of Flavonoid, USA, pp. 1-273.

Parubak, A.S., 2013. Senyawa Flavonoid yang Bersifat Antibakteri dari Akway (Drimys becarina Gibbs). Chemistry Progress, 6(1):3437.

Purwanto, A., Kwartiningsih, E. and Mastuti, E., 2012. Pembuatan Zat Warna Alami dalam Bentuk Serbuk untuk Mendukung Industri Batik di Indonesia. Jurnal Rekayasa Proses, 6(1):26-29.

Paryanto, Wibowo, W.A. \& Aditya M.H. 2016. Pembuatan Zat Warna Alami dari Buah Mangrove Spesies Rhizopora stylosa sebagai Pewarna Batik Ramah Lingkungan dalam Skala Pilot Plan, Seminar Nasional Teknologi Pengolahan Limbah XIV, BATAN dan Sekolah Ilmu Lingkungan UI, Jakarta, Hal 76 - 81.

Punrattanasin, N., Nakpathom, M., Somboon, B., Narumol, N., Rungruangkitkrai, N. \& Mongkholrattanasit, R. 2013. Silk fabric dyeing with natural dye from mangrove bark (Rhizophora apiculata Blume) extract. Industrial Crops and Products, 49: 122-129.

Purnaningtyas, D.N. and Sriyanto, S., 2014. Desain Eksperimen Pewarna Alam Batik Propagul Mangrove dengan Tingkat Ketahanan Luntur
Warna yang Baik dengan Bantuan Zat Fiksatif Tawas. Industrial Engineering Online Journal, $3(2): 1-8$

Rahim, A.A, Rocca, E., Steinmetz, J., Kassim, M.J., Adnan, R., \& Ibrahim, M.S. 2007. Mangrove Tannins and Their Flavanoid sMonomers as Alternative Steel Corrosion Inhibitors in Acidic Medium, Corrosion Science, 49:402 - 417.

Setiawati, E., Nursiam, N. and Zulfikar, Z., 2015. Pengembangan Komoditas Batik: Determinasi Budaya Ekonomi dan Perubahan Struktur Kebijakan Terhadap Perkembangan Usaha Ekonomi Lokal (Studi Tentang Pengusaha Batik Laweyan Surakarta). Jurnal Ekonomi Dan Bisnis, 18(1):119-134.

Sudarmadji. 2004. Species description of Rhizophoraceae family in mangrove forest at Baluran Nasional Park East Java. Biodiversitas, 5(2):66-70.

Umbreen, S., Ali, S., Hussain, T. \& Nawaz, R. 2008. Dyeing Properties of Natural Dyes Extracted from Turmeric and their Comparison with Reactive Dyeing. Research Journal of Textile and Apparel,12(4):1-11. 